\title{
Assessment of Livelihood Vulnerability to Rainfall Variability among Crop Farming Households in Kitui South Sub-County, Kenya
}

\author{
Morris M. Mwatu*, Charles W. Recha, Kennedy N. Ondimu \\ Department of Geography, Egerton University, Njoro, Nakuru, Kenya \\ Email: *mmmwatu76@gmail.com
}

How to cite this paper: Mwatu, M.M., Recha, C.W. and Ondimu, K.N. (2020) Assessment of Livelihood Vulnerability to Rainfall Variability among Crop Farming Households in Kitui South Sub-County, Kenya. Open Access Library Journal, 7: e6317.

https://doi.org/10.4236/oalib.1106317

Received: April 12, 2020

Accepted: June 2, 2020

Published: June 5, 2020

Copyright $\odot 2020$ by author(s) and Open Access Library Inc.

This work is licensed under the Creative Commons Attribution International License (CC BY 4.0).

http://creativecommons.org/licenses/by/4.0/

\section{(c) (i) Open Access}

\begin{abstract}
Rainfall variability has negatively impacted rain-fed crop farming in arid and semi-arid lands increasing households' vulnerability. This study sought to establish the extent to which rain-fed crop farming households in Kitui South sub-County in semi-arid Southeastern Kenya are vulnerable to rainfall variability. The study used index-based approach where Livelihood Vulnerability Index (LVI) for each of the randomly sampled 311 households was calculated using the IPCC framework. Rainfall data for six rainfall seasons for the period 2016-2018 was used to calculate index for exposure while questionnaires were administered to the household heads to establish sensitivity and adaptive capacity indices. Responses from the selected sub-components were assigned index values ranging between zero and one. LVI levels were scored between -1 and +1 . The study established that indices for exposure, sensitivity and adaptive capacity were $0.71,0.09$ and 0.19 respectively and that $97.4 \%$ of the households in the study area were vulnerable to rainfall variability. The study concludes that households in the study area have different livelihood vulnerability levels to rainfall variability due to differences in their sensitivity and adaptive capacity. The study recommends use of households' LVI levels in determining appropriate intervention measures to effects of vulnerability to rainfall variability among different farming households in order to avoid generalization.
\end{abstract}

\section{Subject Areas \\ Geography, Agro-Climatology}

\section{Keywords}

Livelihood Vulnerability, Exposure, Sensitivity, Adaptive Capacity 


\section{Introduction}

Climate influences human activities on the earth's surface including agriculture [1]. Rainfall variability has a lot of adverse effects on livelihoods. This affects mainly agriculture and therefore lowering income of rain dependent farmers making them vulnerable. Many people across the world are vulnerable to rainfall variability due to their high dependence on the agricultural sector especially rain-fed farming [2].

Livelihood vulnerability is determined by three main contributing factors: exposure, sensitivity and adaptive capacity. Exposure refers to the presence of property, systems, people or other elements in hazard places that are subjected to potential losses [3] [4]. Exposure to rainfall variability is brought about by unfavourable characteristics in rainfall onset, cessation, amount, duration or number of rainy days and within-season dry spell in a given rainfall season. Sensitivity is the degree to which people, property or a given system is affected by effects of a given risk [5]. This is mainly determined by socio-economic characteristics of such people or system exposed to the risk. Adaptive capacity is people's or a system's ability to adjust to prevailing extreme events created by risk they are exposed to.

Vulnerability assessment is determined by the conceptual framework chosen by a researcher and the specific risks to be measured [6]. It has been guided by different disciplines such as disaster management (including climate change), anthropology/sociology and economics. Vulnerability arises from exposure of hazard on existing livelihood options of communities and the subsequent response by the communities [7]. When farming communities are exposed to a given risk, their vulnerability will depend on subsequent responses they will engage in. The IPCC framework is based on integrated approach. It conceptualizes vulnerability as an integrated measure of the expected magnitude of adverse impacts resulting from a given level of external stressors [8]. It considers both external (exposure) and internal (sensitivity and adaptive capacity) dimensions to vulnerability.

In Africa, arable land use trends show that tillage fluctuates significantly in response to rainfall changes making rain-fed farming communities vulnerable [9]. Rainfall variability, among other factors, is projected to lead to decrease in agricultural production in Africa up to $50 \%$ by the year 2050 [8]. This is an indication that vulnerability to rainfall variability of households in this area is increasing as majority depend on rain-fed agriculture.

About $80 \%$ of Kenya is located in arid and semi-arid land characterized by high rainfall variability in terms of onset, cessation, amount, duration and distribution [10]. Despite agriculture being a key sector in the economic development of the country, it is mainly rain-fed and therefore vulnerable to rainfall variability [11].

Kitui County was ranked the $12^{\text {th }}$ poorest among the counties of Kenya in the 2015/2016 Kenya Integrated Household Budget Survey report [12]. About 50\% 
of the population lives below poverty line which is far much above the national figure of $36.1 \%$ [12]. Since majority of the population rely on crop farming for their livelihood, most are food insecure. Effects of rainfall variability are spatio-temporal and are usually greater among the poor farmers [13]. This exposes such households in Kitui County to food insecurity and general deterioration in their livelihoods.

Rain-fed agriculture is the main economic activity in Kitui South sub-County and therefore highly affected by rainfall variability [14]. Livelihood vulnerability assessment has not been undertaken to establish the extent to which rain-fed crop farmers in this area are vulnerable to rainfall variability. The current study, therefore, sought to assess livelihood vulnerability in the study area so as to determine specific household level mitigation measures.

\section{Research Methodology}

\subsection{Study Area}

Kitui South sub-County (Figure 1) is located in the semi-arid Southeastern Kenya. Over $87 \%$ of the residents derive their livelihoods from agriculture [14]. The area is generally lowland and experiences unreliable bimodal rainfall regime with an average annual amount of about $600 \mathrm{~mm}$. The long rains are received

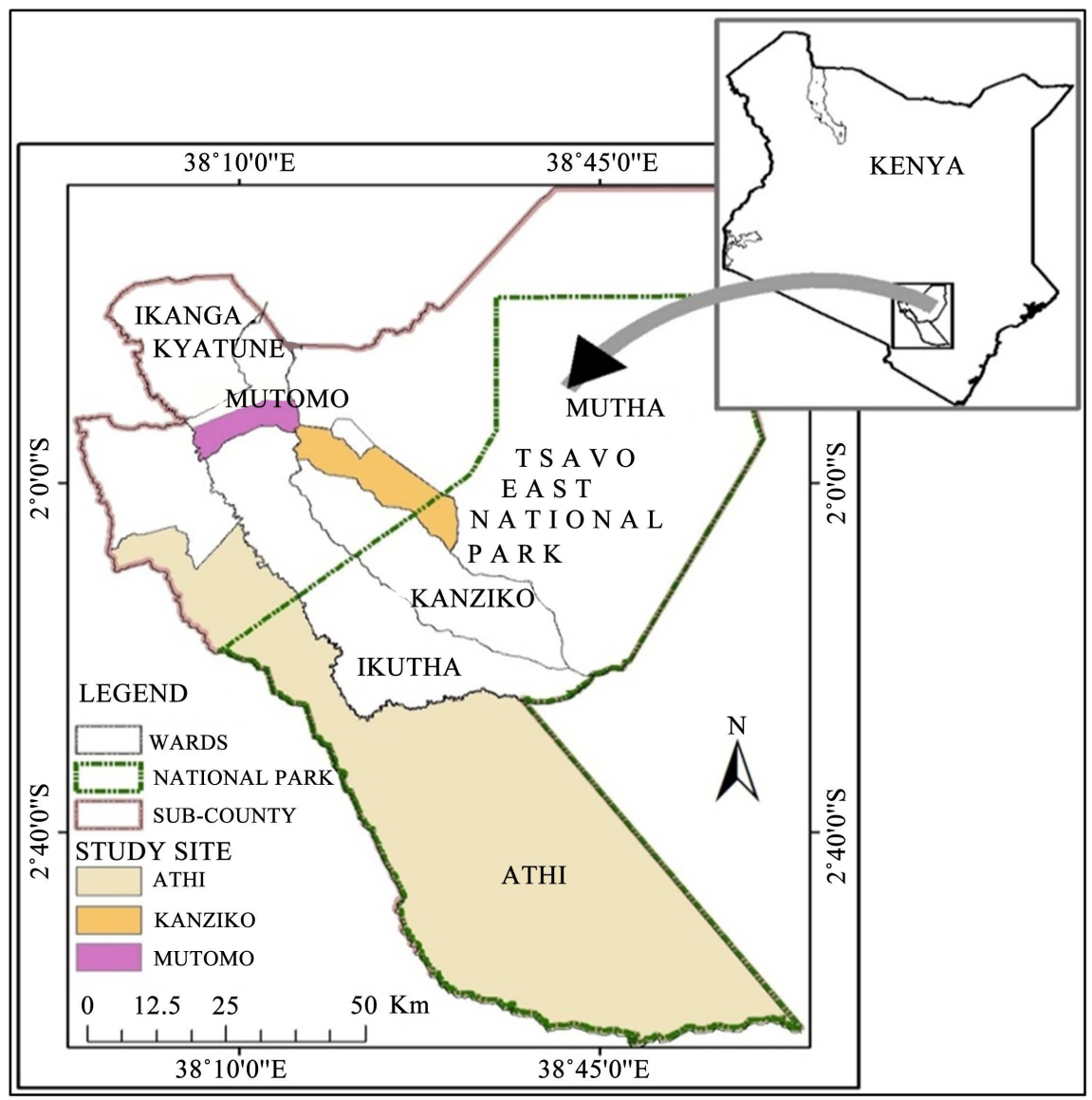

Figure 1. Map of the study area. Source, [15]. 
between March and May while the short rains are received from October to December. The short rains are more reliable for rain-fed farming in the study area. Temperature is generally high ranging between $18^{\circ} \mathrm{C}$ and $34^{\circ} \mathrm{C}$ [14].

The sub-County has four main agro-ecological zones (AEZ's) namely: Lower Midland 4 (LM4), Lower Midland 5 (LM5), Inner Lowland 5 (IL5) and Inner Lowland 6 (IL6). Crop farming is mainly practiced in three AEZs of LM4, LM5 and IL5 as agro-ecological zone LM6 receives very little or no rainfall in most of the years. Over $87 \%$ of the residents derive their livelihoods from agriculture with main crops grown being maize, beans, sorghum, millet, green grams, cowpeas and pigeon peas. Most of the households practice subsistence crop farming with few large-scale farms of sorghum and green grams of not more than 60 acres [14].

\subsection{Data Collection and Sampling}

Multi-stage sampling design was used to obtain the administrative locations and households to be included in the study. All administrative wards in the sub-County were listed and clustered into six agro-ecological zones (AEZs) namely LM4, LM5, IL5, IL6, UM3-4 and UM4. Three wards (Athi, Mutomo and Kanziko) were purposively sampled to represent the three main agro-ecological zones, LM5, LM4 and IL5, where crop farming is dominant. Three administrative locations, one from each ward, were also purposively sampled based on proximity to administrative centres for institutional support. These were Mutomo Location (in Mutomo Ward), Athi Location (in Athi Ward) and Kanziko Location (in Kanziko Ward).

Proportional sampling was used to obtain the number of households' heads to be interviewed per location. According to 2009 Kenya's population and housing census, the study area had 3,409 households [16]. A list of all heads of households engaged in crop farming was obtained from the Chief s office of each location to form the sample frame. Krejcie and Morgan formula was used to obtain the number of households to be involved in the study [17]. All households in the sample frame were assigned numbers and a simple random sampling was used to obtain the respondents to be interviewed during the household survey. Makindu Meteorological station was purposively sampled to provide rainfall data for the period 2016-2018 for analyzing rainfall variability. The station was picked since it is the only synoptic meteorological station near the study area with reliable rainfall data. The three-year period was used to provide six rainfall seasons for calculating vulnerability to rainfall variability among the farming households.

Questionnaire was used to collect data from all the sampled households' heads in the study area. Data was collected on socio-demographic, economic and biophysical variables of the households. The questions were semi-structured with dichotomous responses, multiple responses and open ended questions. In addition, secondary data relevant for this study was obtained from existing literature including published reports, journal papers and on-line resources. 


\subsection{Data Analysis}

Variables for calculating vulnerability index were estimated using Hahn et al. (2009) method [18]. The three contributing factors to vulnerability (exposure, sensitivity and adaptive capacity) were used for the study. Table 1 shows the contributing factors to vulnerability as conceptualized in this study. The study used index-based approach to measure levels of vulnerability. Responses from different sub-components (variables) were assigned values depending on their perceived weight. Since each sub-component is measured on a different scale, the UNDP (2007) formula (Equation (1)) was used to transform the scores to unitary values [19].

$$
t V_{s b}=\left(S_{b}-S_{\text {min }}\right) \div\left(S_{\text {max }}-S_{\text {min }}\right)
$$

where;

$t V_{s b}$ is the transformed value of a sub-component,

$S_{b}$ is the value obtained for the sub-component,

$S_{\min }$ is the minimum value for the sub-component,

$S_{\max }$ is maximum value for the sub-component.

The transformed values lied between zero ( 0 ) and 1 (one). This was calculated by obtaining average of the transformed sub-components of each factor. The Livelihood Vulnerability Index was then calculated using the IPCC-LVI framework (Equation (2)) for each household [20].

$$
\mathrm{LVI}=(e-a) s
$$

where:

$e$ is the transformed index for exposure,

$a$ is the transformed index for adaptive capacity,

$s$ is the transformed index for sensitivity.

\begin{tabular}{|c|c|c|}
\hline Factor & Component & Sub-components (variables for analysis) \\
\hline \multirow{4}{*}{ Exposure } & \multirow{4}{*}{$\begin{array}{l}\text { Seasonal rainfall } \\
\text { variability }\end{array}$} & - Onset of seasonal rainfall \\
\hline & & - Cessation seasonal rainfall \\
\hline & & - Within-season dry spell \\
\hline & & - $\quad$ Seasonal mean rainfall \\
\hline \multirow{3}{*}{ Sensitivity } & \multirow{3}{*}{$\begin{array}{l}\text { Food security } \\
\text { status }\end{array}$} & $\begin{array}{l}\text { - Number of months a household go without } \\
\text { three meals per day in a year }\end{array}$ \\
\hline & & - Availability of seeds for next planting season \\
\hline & & $\begin{array}{l}\text { - Availability of stock of harvest to last up to the } \\
\text { next harvesting time }\end{array}$ \\
\hline \multirow{5}{*}{$\begin{array}{l}\text { Adaptive } \\
\text { capacity }\end{array}$} & \multirow{2}{*}{$\begin{array}{l}\text { Socio-demographic } \\
\text { profile }\end{array}$} & - Education level of households' heads \\
\hline & & - Gender of households' heads \\
\hline & \multirow{2}{*}{$\begin{array}{l}\text { Livelihood } \\
\text { strategies }\end{array}$} & - Availability of off-farm income \\
\hline & & - Availability of surplus income \\
\hline & Social networks & $\begin{array}{l}\text { - Access to early warning climate information } \\
\text { - Access to relief food }\end{array}$ \\
\hline
\end{tabular}

Table 1. Components of LVI analysis.

Source: Synthesis of literature by Author, 2018. 
The LVI obtained was scaled from negative one $(-1)$ to positive one $(+1)$ and grouped into five categories as shown in Table 2.

\section{Results and Discussion}

Indices for exposure, sensitivity and adaptive capacity for all households in the study area were calculated. This was used to calculate livelihood vulnerability index (LVI) for each household.

\subsection{Exposure}

Daily March-April-May (MAM) and October-November-December (OND) rainfall data for the study area for the previous three years prior to the study was analyzed. Onset dates, cessation dates, number of within-season dry spells and total amount of rainfall for each season in the three years of study was established and indices calculated as shown in Table 3.

Five out of the six seasons experienced late onset of rainfall resulting to a transformed index of 0.83 . Three out of the six seasons experienced early cessation of rainfall giving a transformed index of 0.5 . Five out of the six seasons experienced at one within-season dry spell thus a transformed index of 0.83 . Four out of the six seasons received rainfall amount below the long-term seasonal resulting to a transformed index of 0.67 .

The study established that rainfall onset dates were inconsistent for the three years. This is contrary to the finding of Camberlin et al. (2009) who established more consistency of onset dates in Tanzania [21]. However, this finding corresponds to that of Bibi et al. (2014) who established that semi-arid Northern Nigeria generally experienced late onsets which were the main cause of crop failure in

Table 2. Scores for levels of livelihood vulnerability index.

\begin{tabular}{cc}
\hline Score & Level of Vulnerability \\
\hline$-1.0--0.7$ & Not vulnerable \\
$-0.6--0.3$ & Least vulnerable \\
$-0.2-0.2$ & Vulnerable \\
$0.3-0.6$ & Highly vulnerable \\
$0.7-1.0$ & Extremely vulnerable \\
\hline
\end{tabular}

Source: Synthesis of Literature by Author, 2018.

Table 3. Seasonal rainfall variability between 2016 and 2018 .

\begin{tabular}{cccccccc}
\hline Year & \multicolumn{2}{c}{2016} & \multicolumn{2}{c}{2017} & \multicolumn{2}{c}{2018} & Index \\
Season & MAM & OND & MAM & OND & MAM & OND & \\
\hline Onset & $3^{\text {rd }} \mathrm{Apr}$ & $1^{\text {st }} \mathrm{Nov}$ & $18^{\text {th }} \mathrm{Apr}$ & $29^{\text {th }}$ Oct & $2^{\text {nd }}$ Mar & $25^{\text {th }}$ Oct & 0.83 \\
Cessation & $12^{\text {th }}$ May & $31^{\text {st }} \mathrm{Dec}$ & $12^{\text {th }}$ May & $21^{\text {st }} \mathrm{Dec}$ & $12^{\text {th }}$ May & $31^{\text {st }}$ Dec & 0.50 \\
Dry spells & 1 & 1 & 1 & 0 & 1 & 1 & 0.83 \\
Rainfall amount & 127.3 & 224.9 & 199.5 & 177.7 & 600.7 & 259.2 & 0.67 \\
\hline
\end{tabular}

Source: Survey Data, 2018. 
the region [22]. Late onsets usually arise from false onsets which lead to drying of crops planted during the beginning of rainfall seasons, a situation common in Africa [23]. The study also established that $50 \%$ of the rainfall seasons during the period of study experienced early cessation. This finding is similar to that of Mugalavai et al. (2008) who established that generally lowlands generally experienced early cessation which is one of the main causes of rainfall failure in Kenya [24].

Index for exposure was therefore: $(0.83+0.50+0.83+0.67) \div 4=0.71$. This is a high index as its range is between zero (0) to one (1). This implies that people of Kitui South sub-County are greatly vulnerable to the analyzed attributes of rainfall variability. In their study on determinants of livelihood vulnerability among farming communities in the Asian highlands, Sujakhu et al. (2018) established the average vulnerability index for households to be 0.26 [25]. This index is much lower than that Kitui South sub-County due to the fact that semi-arid lowlands are likely to be affected by effects of rainfall variability as compared to highlands.

The index (0.71) obtained was used in calculating LVI for each sampled household across the study area since data on rainfall variations was obtained from one meteorological station. There was, therefore, no variations considered among the households in study area. This is contrary to the findings of Etwire et al. (2013) on use of LVI in assessing vulnerability to climate change and variability in Ghana where exposure was found to vary from region to region [26]. This could have been attributed to use of varied meteorological stations spread across the area of study.

\subsection{Sensitivity to Rainfall Variability}

The study established that majority of the households had difficulties accessing three meals in a day for entire twelve months of the year. Only $6.8 \%$ of the households could afford three meals in a day. This indicates that households in Kitui South sub-County are likely to have a higher sensitivity to rainfall variability. Female-headed households had the highest number of months that their family could not have three meals in a day with the majority (35.7\%) being those who missed three meals in all the twelve months. Households headed by people aged between 36 and 50 years were the highest in missing three meals in all the months. However, no households headed by the young (less than 35 years) and the aged (over 65 years) people had three meals in a day for all the twelve months.

About $37.0 \%$ of households headed by a person with primary education level did not have three meals in a day for the twelve months but, in general, none of the households headed by people with informal education had three meals in a day for the twelve months. The larger the size of households, the more they were unable to have three meals in a day. None of the households with members between 11 and 15 had three days in a day for all months while all households with over 15 members had up to five months without three meals in a day. A consi- 
derable number of households (36.7\%) earning an income of less than 5,000 Kenya shillings per month did not have three meals in a day for all the twelve months. This finding is similar to that of Sabila (2014) who established that the lower the income, the less the number of meals households had in a day in Mount Elgon sub-County in western Kenya [27].

Majority (61.4\%) of the households did not have stock of seeds for planting in the next rainfall season. There were high percentages of male-headed than female-headed households without stock of seeds for planting during the next rainfall season. This may be associated with the tendency of women to preserve some seeds during bumper harvest unlike men who normally sell, a practice passed from generation to another. This finding is similar to that of Njuguna et al. (2016) who found out that very few male headed households had access to pigeonpea seeds in Eastern Kenya prior to planting seasons [28]. Generally, many crop farmers lack access to modern seed varieties specifically developed to adapt to specific environmental conditions [29]. The situation may even be worse to poor farmers as they are not likely to have access even to traditional seed varieties.

The study also established that majority (92.6\%) of respondents did not have stock of crop produce to last them up to next harvest. This is similar to the finding of Sabila (2014) who established that only 3.4\% of rural households of rural Mount Elgon sub-County had crop harvest in granaries [27]. This can be attributed to seasonal rainfall variability where late onsets, low amounts of rainfall, long within-season dry spells and early cessations of rainfall make most crops dry before reaching maturity. The study further established that no female-headed household had stock of crop harvest in the study area. Majority of households with stock of crop harvest were those headed by people without formal education and the aged. This may be attributed to the fact that these households' heads are keen in preserving food crops harvested rather than selling as they may not have sources income to buy food during shortages.

The average sensitivity index for households in the study area was found to be 0.09 . This was generally a low score. This index score was lower than an average score of 0.4 that Sujakhu et al. (2018) found out among farming communities in the Asian highlands [25].

\subsection{Adaptive Capacity to Rainfall Variability}

The study established that $34.7 \%$ of the households were headed by females and $21.5 \%$ of the household heads had no formal education. Male headed households are likely to have higher resilience to extreme climatic conditions such as drought as most of them can seek off-farm employment opportunities to support their families while female headed households are generally disadvantaged [30]. Likewise an educated household head is likely to be more receptive to inventions and innovations developed to improve resilience to harsh climatic conditions [31]. 
Nine percent $(9.0 \%)$ of the households in the study area relied solely on crop farming for income. Despite majority (56.6\%) of the households' income bracket being below 5000 Kenya shillings, most of the households (61.7\%) required between 10,000 and 50,000 Kenya shillings for their monthly expenditure. This implies that it is only a few households whose monthly income surpassed their estimated monthly required expenditure and therefore majority did not have savings. This could probably be due to the fact that a lot of income is used in buying food by households in the study area.

The study also established that majority (92.3\%) of the households had access to early warning on seasonal climatic outlook. This finding corresponds to that of Muema (2018) who found that access to climate information in dry lands was very high [32]. The rate of access to relief food in the study area was low (40.2\%). The low access to relief could have been as a result of government policy of those who qualify for the same or inadequacy of the relief food.

The average adaptive capacity index for households in the study area was found to be 0.19 . This was a higher score than that of sensitivity but lower than that of adaptive capacity. This can be associated with results of the contributing sub-components of adaptive capacity status used to compute index of this component. Most of the households in the study area did not have access to relief food. Sources of income for most of the households were agricultural related activities which are affected by rainfall variability contributing to their low income. Although majority of the households accessed seasonal climate information prior planting seasons, this did not contributed significantly to adaptation to rainfall variability due to their low income which may have hindered acquisition of the required farming inputs.

\subsection{Livelihood Vulnerability Index of Households}

Livelihood vulnerability index (LVI) for each of the 311 sampled households in the study area was calculated and scored between -1 and +1 . The minimum household score was found to be -0.40 and maximum score of 0.34 with a mean score of 0.045 and a standard deviation of 0.06767 . The mean score lies in the "vulnerable" category in the vulnerability scale (Table 4). This is an indication that the households in the study area are generally vulnerable to rainfall variability.

Table 4. Categorized LVI levels for households.

\begin{tabular}{ccc}
\hline Level & Number & Percentage \\
\hline Not vulnerable & 0 & 0.0 \\
Less vulnerable & 1 & 0.3 \\
Vulnerable & 303 & 97.4 \\
Highly vulnerable & 7 & 2.3 \\
Extremely vulnerable & 0 & 0.0 \\
Total & 311 & 100.0
\end{tabular}

Source: Survey Data, 2019. 
Households in the study area were categorized into levels of their vulnerability. The results are shown in Table 4.

Majority (97.4\%) of the households lied in the level of "vulnerable". There were no households in the two categories of "not vulnerable" and "extremely vulnerable". Lack of extremely vulnerable households to rainfall variability may be due to the fact that all households reported to have been having some adaptive capacity despite the high rate of exposure. However, households found even in the same agro-ecological zone can have different vulnerability levels largely due to variations in socio-economic characteristics such as gender and income levels [33].

The study further sought to determine vulnerability levels of households based on their varied socio-economic characteristics. A cross-tabulation between categorized levels of vulnerability and major socio-economic characteristics of households was done (Table 5). Despite most of the households being in vulnerability category (Table 4), this varied among various contributing factors to

Table 5. Levels of vulnerability and socio-economic characteristics.

\begin{tabular}{|c|c|c|c|c|}
\hline \multicolumn{2}{|c|}{ Socio-economic Characteristics } & \multirow{2}{*}{$\begin{array}{c}\text { Less Vulnerable } \\
1(0.01 \%)\end{array}$} & \multirow{2}{*}{$\begin{array}{c}\text { Vulnerable } \\
197(97.04 \%)\end{array}$} & \multirow{2}{*}{$\begin{array}{c}\text { Highly Vulnerable } \\
5(2.46 \%)\end{array}$} \\
\hline \multirow{5}{*}{ Level of education } & Male & & & \\
\hline & Female & $0(0.00 \%)$ & $106(98.15 \%)$ & $2(1.85 \%)$ \\
\hline & Non-formal & $1(1.49 \%)$ & $64(95.52 \%)$ & $2(2.99 \%)$ \\
\hline & Primary & $0(0.00 \%)$ & $179(100.0 \%)$ & $0(0.00 \%)$ \\
\hline & Secondary & $0(0.00 \%)$ & $48(100.0 \%)$ & $0(0.00 \%)$ \\
\hline \multirow{5}{*}{$\begin{array}{l}\text { Age of household } \\
\text { heads (years) }\end{array}$} & Tertiary & $0(0.00 \%)$ & $12(70.59 \%)$ & $5(29.41 \%)$ \\
\hline & Below 35 & $0(0.00 \%)$ & $29(100.0 \%)$ & $0(0.00 \%)$ \\
\hline & $36-50$ & $0(0.00 \%)$ & $122(96.06 \%)$ & $5(3.94 \%)$ \\
\hline & $51-65$ & $0(0.00 \%)$ & $88(100.0 \%)$ & $0(0.00 \%)$ \\
\hline & Over 65 & $1(1.49 \%)$ & $64(95.52 \%)$ & $2(2.99 \%)$ \\
\hline \multirow{4}{*}{$\begin{array}{l}\text { Members of } \\
\text { Households }\end{array}$} & Below 5 & $0(0.00 \%)$ & $56(94.92 \%)$ & $3(5.08 \%)$ \\
\hline & $5-10$ & $0(0.00 \%)$ & $192(98.97 \%)$ & $2(1.03 \%)$ \\
\hline & $11-15$ & $1(1.92 \%)$ & $49(94.23 \%)$ & $2(3.85 \%)$ \\
\hline & Over 15 & $0(0.00 \%)$ & $6(100.0 \%)$ & $0(0.00 \%)$ \\
\hline \multirow{3}{*}{ Source of Income } & Crops only & $0(0.00 \%)$ & $23(82.14 \%)$ & $5(17.86 \%)$ \\
\hline & Crops/livestock & $1(0.66 \%)$ & $148(98.01 \%)$ & $2(1.32 \%)$ \\
\hline & Non-agriculture & $0(0.00 \%)$ & $132(100.0 \%)$ & $0(0.00 \%)$ \\
\hline \multirow{4}{*}{$\begin{array}{c}\text { Monthly Income } \\
\text { (KES) }\end{array}$} & Less than 5000 & $0(0.00 \%)$ & $176(100.0 \%)$ & $0(0.00 \%)$ \\
\hline & $5000-10,000$ & $1(1.01 \%)$ & 93 (93.94\%) & $5(5.05 \%)$ \\
\hline & $10,000-50,000$ & $0(0.00 \%)$ & 33 (94.29\%) & $2(5.71 \%)$ \\
\hline & Over 50,000 & $0(0.00 \%)$ & $1(100.00 \%)$ & $0(0.00 \%)$ \\
\hline \multirow{4}{*}{ Years of Farming } & Less than 5 & $0(0.00 \%)$ & $5(100.0 \%)$ & $0(0.00 \%)$ \\
\hline & $5-10$ & $0(0.00 \%)$ & $20(100.0 \%)$ & $0(0.00 \%)$ \\
\hline & $10-20$ & $0(0.00 \%)$ & $50(100.0 \%)$ & $0(0.00 \%)$ \\
\hline & Over 20 & $1(0.42 \%)$ & $228(96.61 \%)$ & $7(2.97 \%)$ \\
\hline
\end{tabular}

Source: Survey data, 2019. 
LVI. Female headed households had higher percentage (98.15\%) of households in vulnerability than the male headed households (97.04\%). No female headed household was less vulnerable as it was with male headed households. This shows that female headed households are generally more vulnerable compared to their male counterpart. This may be attributed to factors such as low size of cultivated land, low access to three meals in a day, shortages of seed for planting and lack of stock of crop to last households up to the next harvest.

All household headed by people with primary and secondary level of education were found to be vulnerable with those with primary level taking lead. Surprisingly, despite vulnerability generally reducing with education level of the household head, $1.49 \%$ of those with non-formal education were less vulnerable and $29.41 \%$ of those with tertiary education being highly vulnerable. The occurrence of less vulnerable households among household heads with non-formal education may be due to the fact that this is the category which was leading in having stock of planting seeds and stock of food to last up to the next harvest.

A comparison of vulnerability levels among different age groups revealed that $96.06 \%$ of households headed by people aged between 36 and 50 years were vulnerable. Although this formed the majority of households, this result can be attributed to fewer years of experience in farming under variable rainfall conditions. Households headed by the aged (over 65 years) spread across the three levels of vulnerability. In this category, households who were less vulnerable could be attributed to many years of experience while those who were highly vulnerable may be due the fact majority lacked stock of crop to last them up to the next harvesting season and therefore majority lacking three meals in a day for most part the year.

The level of vulnerability increased with number of members in households. For instance all households with members exceeding 15 were found to be vulnerable to rainfall variability. This may be associated with difficulties that such households have in getting sufficient provision for these large household members. However, less vulnerable households were found among those with between 11 and 15 members. This could be associated with adequate labour provided by such members in farmland and income from off-farm sources.

Vulnerability generally decreased with increase in level of income of the households as the highly vulnerable were those whose income level was below 50,000 Kenya shillings. This may be attributed to availability of income sufficient to cushion such households against effects of rainfall variability. Surprisingly some households (2.97\%) with high farming experience (over 20 years) were highly vulnerable. This is contrary to the expectation that such households' heads would use their farming experience in promoting appropriate strategies on adaptation to rainfall variability. This may be associated with decrease in interest in adaptation after long years of farming without much improvement.

\section{Conclusions and Recommendations}

In conclusion, our findings indicate that majority of the households in the study 
area are vulnerable to rainfall variability. This has been contributed to high exposure to rainfall variability in terms of onset, cessation, number of rainy days and rainfall amount. Households also have low adaptive capacity to rainfall variability. Female-headed households are more vulnerable to rainfall variability. Vulnerability generally decreased with level of education, income level of households, experience in farming and size of land under cultivation. On the other hand, vulnerability increased with age of the household head and the number of household members. Households with members getting income from non-agricultural activities are less vulnerable.

The study recommends that interventions on vulnerability should be informed by exposure, sensitivity and adaptive capacity at household levels in order to avoid generalization. Education of women in the study area should also be encouraged so as to empower female-headed households and promote family planning. Households should strive to widen income generating activities to complement agriculture. Both the national and county governments as well as non-governmental organizations should support households in provision of relief food and farm inputs.

\section{Acknowledgements}

The authors wish to sincerely thank the Kenya Meteorological Department for providing rainfall data used in this study. We also extend our gratitude to Kitui County Agriculture and Livestock Extension Service for providing useful information which gave shape to this study. We further thank the government administration in the study area for their support and authorization during data collection. Finally we express our gratitude to all respondents who willingly participated in the study as well as scholars, editors and publishers of journals, articles and books from where the literature of this work has been referred.

\section{Conflicts of Interest}

The authors declare no conflicts of interest regarding the publication of this paper.

\section{References}

[1] Oweis, T. and Hachum, A. (2012) Supplementary Irrigation: A Highly Efficient Water-Use Practice. ICARDA, Aleppo, Syria.

[2] Madu, I.A. (2012) Spatial Vulnerability of Rural Households to Climate Change in Nigeria: Implication for Internal Security. Working Paper No. 2; May 2012: The Robert S. Strauss Center for International Security and Law at the University of Texas, USA.

[3] Yuga, N.G. Shivakoti, P.G. and Sylvain, R.P. (2010) Household-Level Vulnerability to Drought in Hill Agriculture of Nepal: Implications for Adaptation Planning. International Journal of Sustainable Development and World Ecology, 17, 225-230. https://doi.org/10.1080/13504501003737500

[4] Tessema I. and Simame, B. (2019) Vulnerability Analysis of Smallholder Farmers to 
Climate Variability and Change: An Agro-Ecological System-Based Approach in Fincha'a Sub-Basin of the Upper Blue Nile Basin of Ethiopia. Ecological Processes, 8, Article No. 5. https://doi.org/10.1186/s13717-019-0159-7

[5] Paavola, J. (2008) Livelihoods, Vulnerability and Adaptation to Climate Change in Morogoro, Tanzania. Environmental Science and Policy, 11, 642-654. https://doi.org/10.1016/j.envsci.2008.06.002

[6] Adger, W.N. (2006) Vulnerability. Global Environmental Change, 16, 268-281. https://doi.org/10.1016/j.gloenvcha.2006.02.006

[7] Holzmann, P., Boudreau, T., Holt, J., Lawrence, M. and O’Donnell, M. (2008) The Household Economy Approach: A Guide for Programme Planners and Policy-Makers. Save the Children, London.

[8] IPCC (2014) Climate Change 2014: Impacts, Adaptation and Vulnerability, Summary for Policymakers, Working Group II Contributing to the Intergovernmental Panel on Climate Change Fifth Assessment Report. Cambridge University Press, Cambridge.

[9] Kori, E., Gondo, T. and Madilonga, R. (2012) The Influence of Rainfall Variability on Arable Land Use at Local Level: Realities from Nzhelele Valley, South Africa. Proceedings of the International Conference on Future Environment and Energy IPCBEE, 28, 218-223.

[10] Omoyo, N., Wakhungu, J. and Oteng, S. (2015) Effects of Climate Variability on Maize Yield in the Arid and Semi-Arid Lands of Lower Eastern Kenya. Agriculture and Food Security, 4, Article No. 8. https://doi.org/10.1186/s40066-015-0028-2

[11] Allamano, P., Seckler, D. and Makin, I.I. (2010) Estimating the Potential of Rain-Fed Agriculture: Working Paper 20. International Water Management Institute, Colombo.

[12] Republic of Kenya (2018) Kenya Integrated Household Budget Survey (KIHBS) Report. KNBS, Nairobi.

[13] Brooks, N. and Adger, W.N. (2005) Assessing and Enhancing Adaptive Capacity. In Chopra, K., Leemans, R., Kumar, P. and Simons, H., Eds., Adaptation Policy Frameworks for Climate Change: Developing Strategies, Policies and Measures, CUP, Cambridge, 165-181.

[14] Republic of Kenya (2014) The Kitui County Integrated Development Plan 2013-2017. Government Printer, Nairobi.

[15] Independent Electoral and Boundaries Commission (IEBC) (2012) National Assembly Constituencies and County Assembly Order. Government Printer, Nairobi.

[16] Republic of Kenya (2010) Kenya National Bureau of Statistics: 2009 Kenya Population and Housing Census, Vol. 1A. Government Printer, Nairobi.

[17] Krejcie, R.V. and Morgan, D.W. (1970) Determining Sample Size for Research Activities. Educational and Psychological Measurement, 30, 607-610. https://doi.org/10.1177/001316447003000308

[18] Hahn, M.B., Riederer, A.M. and Foster O.S. (2009) The Livelihood Vulnerability Index: A Pragmatic Approach of Assessing Risks from Climate Variability and Change-A Case Study in Mozambique. Global Environmental Change, 19, 74-88. http://www.sage.wisc.edu https://doi.org/10.1016/j.gloenvcha.2008.11.002

[19] UNDP (2007) Human Development Reports. http://hdr.undp.org/en/

[20] IPCC (2007) Climate Change 2007: Impacts, Adaptation and Vulnerability, Working Group II Contribution to the Intergovernmental Panel on Climate Change 
Fourth Assessment Report. IPCC, Geneva.

[21] Camberlin, P., Moron, V., Okoola, R., Philippon, N. and Gitau, W. (2009) Components of Rainy Seasons' Variability in Equatorial East Africa: Onset, Cessation, Rainfall Frequency and Intensity. Theoretical and Applied Climatology, 98, 237-249. https://doi.org/10.1007/s00704-009-0113-1

[22] Bibi, U.M., Kaduk, J. and Balzter, H. (2014) Spatio-Temporal Variations and Prediction of Rainfall in Northeastern Nigeria. Climate, 2, 206-222. https://doi.org/10.3390/cli2030206

[23] Dunning, C.M., Black, E.C. and Allan, R.P. (2016) The Onset and Cessation of Seasonal Rainfall over Africa. Journal of Geophysical Research: Atmosphere, 121, 11,405-11,424. https://doi.org/10.1002/2016JD025428

[24] Mugalavai, E.M., Kipkorir, E.C., Raes, D. and Rao, M.S. (2008) Analysis of Rainfall Onset, Cessation and Length of Growing Season for Western Kenya. Agricultural and Forest Meteorology, 148, 1123-1135. https://doi.org/10.1016/j.agrformet.2008.02.013

[25] Sujakhu, N.M., Ranjitkar, S., Niraula, R.R., Salim, M.A. and Xu, J. (2018) Determinants of Livelihood Vulnerability in Farming Communities in Two Sites in the Asian Highlands. Water International, 43, 165-182. https://doi.org/10.1080/02508060.2017.1416445

[26] Etwire, P.M., Hassan, R.M. and Kowumu, J.K.M. (2013) Application of Livelihood Vulnerability Index in Assessing Vulnerability to Climate Change and Variability in Northern Ghana. Journal of Environment and Earth Sciences, 3, 157-170.

[27] Sabila, S.C. (2014) Factors That Influence Food Security and Rural Households of Mount Elgon Sub-County, Kenya. Master's Thesis, University of Nairobi, Kenya.

[28] Njuguna, E., Mwema, C. and Kandiwa, V. (2016) Beyond a Unitary Household Measure: Does Gender Matter in Legume Seed Systems among Smallholder Farmers? Invited Poster Presented at the 5th International Conference of the African Association of Agricultural Economists, September, 23-26, 2016, Addis Ababa, Ethiopia.

[29] Vizcayno, J.F., Hugo, W. and Alvarez, J.S. (2014) Appropriate Seed Varieties for Small-Scale Farmers: Key Practices for DRR Implementers. FAO, London.

[30] Sujakhu, N.M., Ranjitkar, S., Niraula, R.R., Salim, M.A. and Xu, J. (2019) Assessing the Livelihood of Rural Indigenous Households to Climate Changes in Central Nepal, Himalayas. Sustainability, 11, 1-18.

[31] Recha, C.W., Shisanya, C.A., Makokha, G.L. and Kinuthia, R.N. (2008) Perception and Use of Climate Forecast Information amongst Small-Holder Farmers in Semi-Arid Kenya. Asian Journal of Applied Sciences, 1, 128-135. https://doi.org/10.3923/ajaps.2008.123.135

[32] Muema, E.M. (2018) Determinants of Access and Use of Climate Information Services among Smallholder Farmers in Makueni County, Kenya. Unpublished Master's Thesis, University of Nairobi, Kenya.

[33] Antwi-Agyei, P., Dougill, A.J., Fraser, E.D.G. and Stringer, L.C. (2013) Characterising the Nature of Household Vulnerability to Climate Variability: Empirical Evidence from Two Regions in Ghana. Environment, Development and Sustainability, 16, 903-926. 